\title{
Identification of Cutting Types for the Successful Regeneration of Two Plum (Prunus salicina Lindl) Rootstock Varieties
}

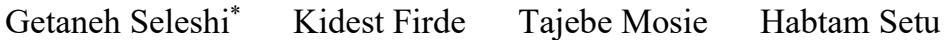 \\ Ethiopian Institute of Agricultural Research, Holeta Research Center, Po. Box.31. Holeta, Ethiopia
}

\begin{abstract}
This study was initiated to identify the best type of cutting for the successful regeneration of two plum rootstock varieties. Three stem cutting types (hardwood, semi-hardwood and softwood) were collected from two plum rootstock varieties (Mariana GF 8-1 and Myrobalan 29C) and have been evaluated for root, shoot and leaf traits. The result revealed that semi-hardwood cuttings of Myrobalan 29C received the earliest (15 days) sprouting while the number of shoots (3.13-3.98) and length $(13.63 \mathrm{~cm})$ were higher in Mariana GF 8-1. The highest sprouting (93.33-96.67\%) were recorded from both hardwood and semi-hardwood cuttings of Mariana GF 8-1. Hardwood and softwood cuttings of Mariana GF 8-1 had also obtained better shoot fresh (12.89-13.26 g) and dry weight (2.67-3.33 g), respectively, while leaf number was higher (43.07) in the hardwood cuttings. The widest (2.34-2.51 $\mathrm{cm}$ ) and longest (4.80-4.81) leaves were obtained from Myrobalan 29C cuttings of all types while the maximum number of roots (37.67), root grade $(7.63)$ and root length $(12.62 \mathrm{~cm})$ were recorded from semi-hardwood and hardwood Myrobalan 29C cuttings, consecutively. The highest rooting percentage $(100.00 \%)$ was observed in the semi-hardwood Mariana GF 8-1 cuttings. Hardwood and softwood Myrobalan 29C plus hardwood and semihardwood Mariana GF 8-1 cuttings had received statistically similar and highest roots fresh weights (14.11-14.33 g). However, hardwood Mariana GF 8-1 cuttings alone had recorded the maximum root dry weight $(4.00 \mathrm{~g})$. Overall, cutting type particularly hardwood cutting could be considered for successful regeneration of both varieties though Mariana GF 8-1 had succeeded Myrobalan 29C in most of the parameters.
\end{abstract}

Key words:Cutting, leaf, plum, root, rootstocks, shoot

DOI: $10.7176 /$ ALST/85-04

Publication date: January $31^{\text {st }} 2021$

\section{Introduction}

Plum (Prunus salicina Lindl) fruits are a diverse group of species that belongs to the Rosaceae family of the genus Prunus. Plum trees grow from seed or propagate through cuttings or grafting. However, trees propagated from seeds may not grow true to seed if the plum is a hybrid variety. Cutting is therefore the most important method of cloning to several crops and the formation capacity of adventitious roots is a prerequisite for success (Hartmann et al., 2002). It is more reliable and produces a fruiting tree much sooner. Since plums are a relatively easy-to-root species, they can also be propagated by hardwood or sometimes softwood cuttings under mist or in hothouses and then transplanted directly into their final location (Hartman et al., 2011; Markovski et al., 2015; Narula and Kaur, 2018). Vegetative propagation by hardwood cuttings is a simple and cheap method of the multiplication of plum rootstocks, which has not been used with great success. Rooting is a complex process that is determined by the relation of many factors such as genetic, buds on the cuttings and the amount of carbohydrate reserve of the cuttings as well as the growth stage of the plant and type of the cutting tissue. The time of cutting collection, physiological status and biochemical features of the mother plant, rooting media, environmental condition and technological factors are also the other major factors that affect the rooting ability (Rosier et al., 2006; Szecskó1 et al., 2006). The rooting percentage is therefore varies from 60 to $100 \%$ in plum species and 74 to $100 \%$ in peach (Swedan et al., 1993; Tsipouridis et al., 2003; Mirabdulbaghi et al., 2011).

The two rootstock varieties namely Myrobalan 29C (Prunus cerasifera) and Mariana GF 8-1 (Prunus cerasifera $\mathrm{x}$ P. munsoniana) are the most commonly used worldwide propagation of plum. These varieties are recommended particularly for soil having nematode (Rahman et al., 2000; Sándor, 2011; Plopa et al., 2012; Naser et al., 2018). Based on this, both of these rootstock varieties were introduced by Holeta Agricultural Research Center from abroad and have been evaluated for their adaptability at Holeta condition. Promising results for growth and performance of both varieties have also been observed regardless of their poor rooting ability from propagation by cuttings. This would probably be because of improper utilization of cutting types, since there is no clearly recommended cutting type in this area. Therefore, this study was conducted to identify the best type of cutting for the successful regeneration of two plum rootstock varieties.

\section{Materials and Methods}

Experimental site

The experiment was conducted during the year 2019 at Holeta Agricultural Research Center, which is located at $9^{\circ} 00^{\prime} \mathrm{N}$ latitude and $38^{\circ} 29^{\circ} \mathrm{E}$ longitude with an altitude of 2400 m.a.s.l., and $40 \mathrm{~km}$ west of Addis Ababa along the Ambo road. The average annual maximum and minimum temperatures of the area are 21.7 and $6.7^{\circ} \mathrm{C}$, 
respectively. It also receives a mean annual rainfall of $1041.4 \mathrm{~mm}$ and the relative humidity of about $58.7 \%$. The main rainy season is June to September, which accounts for $70 \%$ of the rainfall while the remaining $30 \%$ is from February to April (EIAR, 2017).

\section{Methodology}

The experiment had consisted of three cutting types (hardwood, semi- hardwood and softwood cuttings) and two plum rootstock varieties (Mariana GF 8.1 and Myrobalan 29C). Cuttings from two varieties were collected from the current season grown shoots during dormancy period. The cuttings of all types were then prepared to $20 \mathrm{~cm}$ length and 3-4 buds with the lowest bud had about $0.5 \mathrm{~cm}$ distant from the basal end of cuts. Each cutting was treated with $2000 \mathrm{ppm}$ indole-butyric acid (IBA) solution, which was prepared using 50\% ethanol and 50\% distilled water. The cuttings were dipped in the solution for 30 seconds and planted in sterilized sand media with $45^{0}$ slants at $5 \mathrm{~cm}$ apart and placed under glass house. The experiment was assigned using a completely randomized design (CRD) with three replications in factorial arrangement having 10 cuttings per plot. The daily minimum and maximum temperatures had been measured. The sprouting data was collected every four days, while the rooting and shooting data was measured ninety days after planting.

\section{Data collection}

Five samples were randomly selected and the number of shoots, leaves and roots directly arose from each cutting and recorded 90 days after planting. The largest root and shoot length for each sample was recorded using $50 \mathrm{~cm}$ measuring ruler. Rooting performance (grade) of these varieties was subjectively evaluated by using 0 to 9 rating scale; where 0 is for non-rooted and 9 is for profuse root development (Beyl et al., 1995). The rooting percentage for each sample was calculated using the following formula;

$$
\text { Rooting percentage }(\%)=\frac{\text { Number of rooted cuttings }}{\text { Total number of planted cuttings }} X 100
$$

The shoot and root fresh weight of each sample were measured by using electrical sensitive balance and expressed in grams, while the dry weight of these samples were measured after oven dried at a temperature of 55 ${ }^{\circ} \mathrm{C}$ (Ghosh et al., 2017). The root and shoot length as well as the leaf width and length of cuttings were measured using $50 \mathrm{~cm}$ ruler ninety days after planting.

\section{Data analysis}

The analysis of variance (ANOVA) of each parameter was computed using SAS software. The mean comparison between treatments was carried out by using the least significant difference test (LSD) at $0.05 \%$ level of significance (Gomez and Gomez, 1984).

\section{Results and Discussions}

\section{Days of sprouting}

Highly significant $(\mathrm{P} \leq 0.001)$ variation on days of sprouting among treatments was observed due to the interaction effect of variety and cutting types (Table 1). Semi-hardwood cuttings of Myrobalan 29C had the earliest days (15) of sprouting as compared to other treatments while the latest days (28) were recorded on softwood cuttings of Mariana GF 8-1 rootstocks. Statistically earlier days of sprouting were received by all cutting types of Myrobalan 29C than Mariana GF 8-1 cuttings. The earliest days of sprouting in Myrobalan 29C might be due to the difference in rooting ability of cuttings taken from different parts of a plant is considered to be because of a difference in physiological age and genetic. Stored foods such as hydrocarbons are an important feature for rooting that enables these cuttings to grow and develop quickly than other types of cuttings (Agbo and Obi, 2007; Kumar et al., 2011; Yeshiwas et al., 2015).

\section{Number of shoots}

The analysis of variance showed that the interaction effect of variety and cutting type had non-significant $(\mathrm{P} \leq 0.05)$ influence on the number of shoots, while the single factors of varieties as well as cutting types had received highly significant $(\mathrm{P} \leq 0.001)$ differences (Table 1). Of the varieties, Mariana GF 8-1 particularly from hardwood cuttings recorded higher numbers of shoots ranging from 3.13 to 3.98 than Myrobalan 29C cuttings. The lowest (2.00) number of shoots however was observed in semi-hardwood Myrobalan 29C cuttings. This higher number of roots in the hardwood cuttings might be related to the presence of ample carbohydrate reserve, which could be easily utilized for metabolic activities that aid cell division to occur, which brings about root initiation. The genetic make of variety Mariana GF 8-1 could also enhance the shoot development of cuttings compared to Myrobalan 29C. The rooting capability of cuttings varies from cultivar to cultivar and age of branch (Hartmann and Kester, 1983; Wiegel et al., 1984). 


\section{Shoot length}

The shoot length of cuttings received highly significant $(\mathrm{P} \leq 0.001)$ variation due to the interaction effect of variety and cutting type (Table 1). Statistically the longest shoots of $13.63 \mathrm{~cm}$ and $13.03 \mathrm{~cm}$ were recorded in variety Mariana GF 8-1 semi-hardwood cuttings and hardwood cuttings of Myrobalan 29C, respectively. The softwood cuttings of variety Myrobalan 29C obtained the shortest shoot of $8.84 \mathrm{~cm}$. Benabise (2012) reported comparable result on Afzelia rhomboidea. The lowest shoot lengths could be due to the physiological status with low carbohydrate (stored food) accumulation that could enhance cell elongation of the shoots. The shoot growth can be influenced by the food supply (carbohydrate to nitrogen ratio of the stems), age and type of cutting. Cuttings from succulent stems with very low carbohydrate do not succeed due to their herbaceous nature that made them sensitive to desiccation (Gangoo et al., 1997; Kumar, 2000; Singh, 2000).

\section{Sprouting percentage}

The sprouting percentage of the two plum rootstock varieties had highly significant $(\mathrm{P} \leq 0.001)$ variation because of the interaction effect with cutting type (Table 1). Significantly the highest sprouting percentages ranging from 93.33-96.67\% was obtained from both hardwood and semi-hardwood cuttings of Mariana GF8-1. However, the minimum percentages $(50.00 \%)$ were recorded when these cutting types were combined with Myrobalan 29C. Non-significant difference was observed when both varieties were propagated by softwood cuttings. Generally, Mariana GF 8-1 cutting types had recorded more sprouting percentage than Myrobalan 29C. Comparable result from semi-hardwood and hardwood cuttings was reported by Okunlola (2013) using Duranta repens. This might be due to variation in the stored carbohydrate between the varieties.

Table 1 . Effect of variety and cutting type on the shoot and leaf traits of two plum rootstock varieties

\begin{tabular}{|c|c|c|c|c|c|c|c|c|c|c|}
\hline $\begin{array}{l}\text { Treatments } \\
\text { Variety } \\
\text { (A) }\end{array}$ & $\begin{array}{l}\text { Cutting } \\
\text { Type } \\
\text { (B) }\end{array}$ & $\begin{array}{l}\text { DS } \\
\text { (days) }\end{array}$ & NS & $\begin{array}{l}\text { SL } \\
(\mathrm{cm})\end{array}$ & $\begin{array}{l}\text { SP } \\
(\%)\end{array}$ & $\begin{array}{l}\text { SFW } \\
(\mathrm{g})\end{array}$ & $\begin{array}{l}\text { SDW } \\
(\mathrm{g})\end{array}$ & LN & $\begin{array}{l}\mathrm{LW} \\
(\mathrm{cm})\end{array}$ & $\begin{array}{l}\mathrm{LL} \\
(\mathrm{cm})\end{array}$ \\
\hline \multirow{4}{*}{$\begin{array}{ll}\text { Mariana } & \text { GF } \\
8.1 & \end{array}$} & HWC & $19.67^{\mathrm{bc}}$ & $3.98^{\mathrm{a}}$ & $12.23^{\mathrm{c}}$ & $93.33^{\mathrm{a}}$ & $12.89^{\mathrm{a}}$ & $3.33^{\mathrm{a}}$ & $43.07^{\mathrm{a}}$ & $2.05^{\mathrm{b}}$ & $3.75^{\mathrm{c}}$ \\
\hline & SHWC & $21.33^{b}$ & $3.13^{\mathrm{b}}$ & $13.63^{\mathrm{a}}$ & $96.67^{\mathrm{a}}$ & $13.26^{\mathrm{a}}$ & $2.67^{\mathrm{a}}$ & $31.73^{c}$ & $1.94^{\mathrm{b}}$ & $3.42^{\mathrm{c}}$ \\
\hline & SWC & $28.00^{\mathrm{a}}$ & $3.60^{\mathrm{ab}}$ & $12.80^{\mathrm{bc}}$ & $66.67^{b}$ & $4.00^{c}$ & $1.23^{\mathrm{d}}$ & $34.24^{\mathrm{b}}$ & $2.01^{\mathrm{b}}$ & $3.56^{\mathrm{c}}$ \\
\hline & HWC & $18.33^{c}$ & $2.97^{b}$ & $13.03^{\mathrm{ab}}$ & $50.00^{\mathrm{c}}$ & $8.67^{b}$ & $2.47^{b c}$ & $34.23^{\mathrm{b}}$ & $2.39^{\mathrm{a}}$ & $4.80^{\mathrm{a}}$ \\
\hline \multirow{2}{*}{$\begin{array}{l}\text { Myrobalan } \\
29 \mathrm{C}\end{array}$} & SHWC & $15.00^{\mathrm{d}}$ & $2.00^{\mathrm{c}}$ & $9.99^{d}$ & $50.00^{\mathrm{c}}$ & $8.16^{\mathrm{b}}$ & $1.33^{\mathrm{d}}$ & $19.00^{\mathrm{e}}$ & $2.51^{\mathrm{a}}$ & $4.81^{\mathrm{a}}$ \\
\hline & SWC & $20.00^{\mathrm{bc}}$ & $3.35^{\mathrm{ab}}$ & $8.84^{\mathrm{e}}$ & $73.33^{b}$ & $8.03^{b}$ & $2.00^{c}$ & $29.42^{\mathrm{d}}$ & $2.34^{\mathrm{a}}$ & $4.21^{\mathrm{b}}$ \\
\hline \multirow{3}{*}{ Significance } & $\mathrm{A}$ & $* * *$ & $* * *$ & $* * *$ & $* * *$ & $* * *$ & $* *$ & $* * *$ & $* * *$ & $* * *$ \\
\hline & B & $* * *$ & $* * *$ & $* * *$ & ns & $* * *$ & $* * *$ & $* * *$ & ns & $*$ \\
\hline & $A * B$ & $* * *$ & ns & $* * *$ & $* * *$ & $* * *$ & $* * *$ & $* * *$ & ns & $*$ \\
\hline \multirow{2}{*}{$\begin{array}{l}\mathrm{LSD}(\mathrm{P} \leq 0.05) \\
\mathrm{CV}(\%)\end{array}$} & & 2.99 & 0.67 & 0.78 & 11.09 & 0.88 & 0.59 & 2.27 & 0.22 & 0.37 \\
\hline & & 8.26 & 11.74 & 3.74 & 8.70 & 5.38 & 15.34 & 4.00 & 5.60 & 5.12 \\
\hline
\end{tabular}

DS: days of sprouting; HWC: hardwood cutting; LL: leaf length; LN: leaf number; LW: leaf width; NS: number of shoot; ns: non-significant; SDW: shoot dry weight; SFW: shoot fresh weight; SHWC: semi-hardwood cutting; SL: shoot length; SP: sprouting percentage; SWC: softwood cutting

\section{Shoot fresh and dry weight}

The shoot fresh and dry weight of cuttings had highly significant $(\mathrm{P} \leq 0.001)$ influence due to the interaction effect of variety and cutting type (Table 1). Variety Mariana GF 8-1 combined with either hardwood or softwood had received the highest shoot fresh (12.89-13.26 g) and dry weight (2.67-3.33 g), respectively as compared to other treatments. Whereas, the softwood cuttings of this variety had received the lowest shoot fresh weight of $4.00 \mathrm{~g}$ and dry weight of $1.23 \mathrm{~g}$. The shoot fresh weight of Myrobalan 29C at all cutting types had non-significantly $(\mathrm{P} \leq 0.05)$ varied as the shoot dry weight has done. Similar results were reported by Rezende et al. (2010) using Coffea arabica cuttings. The higher shoot fresh and dry weight could probably be due to increased supply of photosynthates from source to sink, which subsequently might have resulted in higher fresh weight and dry matter accumulation (Singh, 2004).

\section{Leaf number, width and length}

Highly significant $(\mathrm{P} \leq 0.001)$ influence by the interaction between variety and cutting type was observed on both leaf number and length. This effect, however, was non-significant $(\mathrm{P} \leq 0.05)$ for leaf width of cuttings plus among the cutting types (Table 1). The maximum leaf number of 43.07 was recorded in the hardwood cuttings of Mariana GF 8-1 while Myrobalan 29C at its most of cutting types had relatively received the minimum leaf number. 
Myrobalan 29C cuttings of all types had better leaf width ranging from 2.34 to $2.51 \mathrm{~cm}$ than others. Besides, the highest leaf lengths of 4.80 to 4.81 were also observed in this variety as compared to other treatments. Agreeable result was reported by Ambebe et al. (2018) using Cordia africana (Lam.) and Antwi-Boasiako and Enninful (2008) on Moringa oleifera cuttings. This could be related to the difference in the genetic makeup of varieties and accumulated carbohydrates on the cuttings.

\section{Number of roots}

Highly significant $(\mathrm{P} \leq 0.001)$ influence on the number of roots was observed as influenced by the interaction effect of variety and cutting type (Table 2). The highest number of roots (37.67) was recorded in the semi-hardwood cuttings of Myrobalan 29C, which was statistically at par (35.33) with the same cutting types of Marian GF 8-1. The minimum numbers of roots were obtained at both the hardwood Mariana GF 8-1 (24.80) and softwood Myrobalan 29C (24.00) cuttings. The highest number of roots in semi-hardwood cuttings of both varieties might be due to the cuttings differed in physiological maturity. Physiologically mature tissues have lower rooting potential and take more time to initiate roots and develop fewer roots than physiologically juvenile tissues (Goel and Behl, 2004).

\section{Root length and grade}

The interaction effect of variety and cutting type had significant $(\mathrm{P} \leq 0.05)$ effect on the root length and grades of cuttings (Table 2). The longest root of $12.62 \mathrm{~cm}$ was obtained from the hardwood cuttings of Myrobalan 29C cuttings while the smallest of $8.33 \mathrm{~cm}$ was recorded at the softwood cuttings of Mariana GF 8-1. Statistically $(\mathrm{P} \leq 0.05)$ similar root lengths were obtained from the hardwood Marian GF 8-1 and semi-hard wood or softwood cuttings of Myrobalan 29C cuttings. Regarding the root grade, the highest (7.63) was recorded from the semihardwood Myrobalan 29C cuttings while the lowest (5.27) was obtained at the hardwood Mariana GF 8-1 cuttings though it was statistically at par with softwood cuttings of this variety. There was non-significant difference among the semi-hardwood Mariana GF 8-1 and softwood Myrobalan 29C cuttings. The highest root length and performance might be due to the variation in the degree of lignifications among the cuttings since hardwood utilize more carbohydrates for lignifications than for rooting as compared to other cutting types.

\section{Rooting percentage}

The analysis of variance (Table 2) revealed that the interaction between variety and cutting type had highly significant $(\mathrm{P} \leq 0.001)$ influence on the rooting percentage of cuttings. The maximum rooting percentage $(100.00 \%)$ was observed in the semi-hardwood Mariana GF 8-1 cuttings. However, the minimum rooting percentages of 46.67, 50.00 and 53.33\% were recorded at hardwood and softwood Myrobalan 29C as well as softwood Mariana GF 8-1 cuttings, consecutively. Comparably, (Saumya et al., 2014a; Saumya et al., 2014b; Nayana et al., 2013) had observed on Salacia reticulata and Embelia ribes. This would probably be due to the genetic variation of the varieties as well as the degree of lignifications on cuttings. The variation in the rooting ability could also be because of the variation in carbohydrate reserve in the cuttings. The rooting success of the cuttings varies with cultivars, endogenous sugars, sucrose and starch as well as type of cuttings (Dick and Dewar, 1992; Hartmann et al., 2002; Tsipouridis et al., 2006).

\section{Root fresh and dry weight}

There was a highly significant $(\mathrm{P} \leq 0.001)$ variation between treatment means on the root fresh and dry weight of cuttings as affected by the interaction between variety and cutting type (Table 2). Statistically the highest root fresh weights ranging from 14.11to $14.33 \mathrm{~g}$ were received from both the hardwood and softwood Myrobalan 29C cuttings that were at par with hardwood and semi-hardwood Mariana GF 8-1 cuttings. Semi-hardwood cuttings of Myrobalan 29C had recorded the lowest $(9.38 \mathrm{~g})$ root fresh weight. Of the root dry weight of cuttings, the best result $(4.00 \mathrm{~g})$ was obtained at the hardwood Mariana GF 8-1 samples while the least (1.11 and $152 \mathrm{~g})$ were observed in the softwood Mariana GF 8-1 and hardwood Myrobalan 29C cuttings, respectively. This could be due to the interaction effect of variety and cutting type. It might also be related to the higher metabolic reserves for root initiation and growth as well as higher rooting potential of the cuttings (Singh et al 2015). 
Table 2. Effect of variety and cutting types on the root traits of the two plum rootstock varieties

\begin{tabular}{|c|c|c|c|c|c|c|c|}
\hline $\begin{array}{l}\text { Treatments } \\
\text { Variety (A) }\end{array}$ & $\begin{array}{l}\text { Cutting } \\
\text { Type (B) }\end{array}$ & NR & $\begin{array}{l}\mathrm{RL} \\
(\mathrm{cm})\end{array}$ & $\mathrm{G}$ & $\begin{array}{l}\text { RP } \\
(\%)\end{array}$ & $\begin{array}{l}\text { RFW } \\
\text { (g) }\end{array}$ & $\begin{array}{l}\text { RDW } \\
\text { (g) }\end{array}$ \\
\hline \multirow{3}{*}{ Mariana GF 8.1} & HWC & $24.80^{c}$ & $10.50^{\mathrm{b}}$ & $5.27^{\mathrm{d}}$ & $76.67^{b}$ & $13.50^{\mathrm{ab}}$ & $4.00^{\mathrm{a}}$ \\
\hline & SHWC & $35.33^{\mathrm{ab}}$ & $9.56^{\mathrm{c}}$ & $6.13^{\mathrm{c}}$ & $100.00^{\mathrm{a}}$ & $12.89^{\mathrm{ab}}$ & $3.33^{\mathrm{b}}$ \\
\hline & SWC & $18.40^{\mathrm{d}}$ & $8.33^{\mathrm{d}}$ & $5.57^{\mathrm{cd}}$ & $53.33^{c}$ & $12.11^{\mathrm{b}}$ & $1.11^{\mathrm{d}}$ \\
\hline \multirow{3}{*}{ Myrobalan 29C } & HWC & $32.30^{\mathrm{b}}$ & $12.62^{\mathrm{a}}$ & $7.77^{\mathrm{b}}$ & $46.67^{\mathrm{c}}$ & $14.11^{\mathrm{a}}$ & $1.52^{\mathrm{d}}$ \\
\hline & SHWC & $37.67^{\mathrm{a}}$ & $10.32^{\mathrm{bc}}$ & $7.63^{\mathrm{a}}$ & $50.00^{c}$ & $9.38^{\mathrm{c}}$ & $2.33^{\mathrm{c}}$ \\
\hline & SWC & $24.00^{c}$ & $11.05^{\mathrm{b}}$ & $6.07^{\mathrm{c}}$ & $66.67^{\mathrm{b}}$ & $14.33^{\mathrm{a}}$ & $2.83^{\mathrm{bc}}$ \\
\hline \multirow{3}{*}{ Significance } & $\mathrm{A}$ & $* * *$ & $* * *$ & $* * *$ & $* * *$ & ns & $* *$ \\
\hline & $\mathrm{B}$ & $* * *$ & $* * *$ & $* * *$ & $* *$ & $* * *$ & $* *$ \\
\hline & $A * B$ & ns & $* *$ & $*$ & $* * *$ & $* * *$ & $* * *$ \\
\hline $\operatorname{LSD}(\mathrm{P} \leq 0.05)$ & & 3.18 & 0.82 & 0.61 & 11.67 & 1.56 & 0.65 \\
\hline $\mathrm{CV}(\%)$ & & 6.21 & 4.44 & 5.47 & 10.01 & 6.87 & 14.60 \\
\hline
\end{tabular}

HWC: hardwood cutting, ns: non-significant, SHWC: semi-hardwood cutting, SWC: softwood cutting, NR: number of roots, $R L$ : root length, $G$ : grade, $R P$ : rooting percentage, $R F W:$ root fresh weight, $R D W:$ root dry weight

\section{Conclusions}

Generally, the regeneration capacity of the two rootstock varieties was significantly varied with stem cutting type. Mariana GF 8-1 cuttings had showed better result in most of the parameters than Myrobalan 29C. Particularly, the former had received better shoot and root growth and development while the later was best for leaf traits. Therefore, cutting type, especially hardwood cutting, could be considered for successful regeneration of both plum root stock varieties.

\section{Acknowledgement}

The authors would like to acknowledge the Ethiopian Institute of Agricultural research for funding this research to be accomplished as well as the researchers that introduced these plum rootstock varieties from abroad, managed and maintained them. The contribution of field and nursery site workers was also praised since it helped to get good quality cuttings.

\section{References}

Agbo, C.U. and Obi, I.U. (2007). Variability in propagation potentials of stem cuttings of different physiological ages of Gongronema latifolia Benth. World Journal of Agricultural Sciences, 3(5):576-581

Ambebe T.F., Agbor A.E.W. and Ngwitoh T.C. (2018). Shoot Development and Survival of Vegetativelypropagated Cordia africana (Lam.) as affected by Type of Cutting. International Journal of Forestry and Horticulture (IJFH). Volume 4, Issue 3, PP 33-37 DOI: http://dx.doi.org/10.20431/2454-9487.0403005.

Antwi-Boasiako C. and Enninful R. (2008). The influence of maturity and length of stem-cutting on the sprouting potential of Moringa oleifera Lam. Journal of Science and Technology, 28:140-151.

Benabise E.V. (2012). Effects of Cutting Positions and Different Levels of Indolebutyric Acid (IBA) on the Survival and Rooting Ability of Tindalo [Afzelia rhomboidea (Blanco) Vidal]. IPCBEE, 41: 200-204.

Beyl C.A., Ghale G. and Zhang L. (1995). Characteristics of Hardwood Cuttings Influence Rooting of Actinidia arguta (Siebold and Zucc.) Planch. Hortscience, 30(5):973-976.

Dick J.M. and Dewar R.C. (1992). A mechanistic model of carbohydrate dynamics during adventitious root development in leafy cuttings. Ann Bot, 70:371-377.

EIAR (Ethiopian Institute of Agricultural Research). (2017). Holeta Agricultural Research Center Progress Report.

Gangoo S.A., Qaisar K.N., Mughal A.H. and Makaya A.S. (1997). Propagation of Ficus palmata Forsk by cuttings. Indian For, 123:87-88.

Ghosh A., Mani A. and Dey K. (2017). Efficacy of different levels of IBA and NAA on rooting of Phalsa (Grewia asiatica L.) cuttings. International Journal of Chemical Studies, 5(6): 567-571.

Gomez K.A. and A.A. Gomez. (1984). In: Statistical procedure for agricultural research. $2^{\text {nd }}$ ed, New York, Willey Interscience, pp 304-309.

Hartman H.T., Kester D.E., Davies F.T. and Geneve R.L. (2011). Plant Propagation: Principles and Practices. $\left(8^{\text {th }}\right.$ Edition). Prentice Hall. NJ, (USA). P. 928.

Hartmann, H.T., Kester, D.E., Davies F.T. and Geneve, R.L. (2002). Plant propagation: principles and practices. $7^{\text {th }}$ Edition. Prentice Hall. New Jersey. p. 277-410.

Hartmann H.T., Kester D.E., Davies Júnior F.T. and Geneve R.L. Plant propagation: principles and practices. $7^{\text {th }}$ ed. New Jersey: Prentice Hall, 2002. 880p. 
Kumar, N. (2000). Introduction to Horticulture. Rajalaxmi Publications, Nagercoil, TamilNadu. 369p.

Kumar N.K. Anand G. V. and Reddy M. P. (2011). Plant regeneration of non-toxic Jatropha curcas-impacts of plant growth regulators, source and type of explants. Journal of Plant Biochemistry Biotechnology, 20(1): 125-133.

Markovski A. M., Popovska and V. Gjamovski. (2015). Investigation of the possibility for production of some stone fruit rootstocks by rooting cuttings. Acta Agriculturae Serbica, 39: 75-831.

Mirabdulbaghi M., Zarghami R. and Azghandi A.V. (2011). Propagation of Tanasgol, a Natural Plum-Apricot Hybrid (Prunus domestica-armenia) Developed in Iran. Trends in Horticultural Research, 1(1):27-31.

Narula S. and Kaur G. (2018). Influence of growth regulators on the regeneration and Survival of plum cv. Kala Amritsari through Stem Cuttings. International Journal of Agriculture Innovations and Research, 7:23192473.

Naser I., Al-Hamad E.T. and Olbinado E.E., (2018). Evaluation of Super High Density Planting of Stone Fruits Cultivars at TADCO, Tabuk, Saudi Arabia. Journal of Agriculture and Allied Sciences, 7: 41-72

Nayana E.K.E., Subasinghe S., Amarasinghe M.K.T.K., Arunakumara K.K.I.U. and Kumarasinghe H.K.M.S. (2015). Effect of maturity and potting media on vegetative propagation of Salacia reticulata through stem cuttings. Intl J Minor Fruits Med Arom Plants, 1:47-58.

Okunlola, A.I. (2013). The effects of cutting types and length on rooting of Duranta repens in the nursery. Global Journal of Human Social Science Volume, XIII Issue III Version I.

Plopa C., Duta I., Isac V., Mazilu C. and Ancu S. (2012). Factors influencing in vitro propagation of Myrobalan dwarf plum rootstock II EUFRIN plum and prune working group meeting on present constraints of plum growing in Europe. ISHS Acta Hortic. P 968.

Rahman N., Nabi G., Khan J. and Shafqatullah. (2000). Vegetative Growth Performance of Different Plum Rootstocks. Pakistan Journal of Biological Sciences, 3 (10): 1630-1631

Rezende T.T., Baliza D.P., Oliveira D.H., Carvalho S.P., Ávila F.W., Passos A.M.A. and Guimarães R.J. (2010). Types of stem cuttings and environments on the growth of coffee stem shoots. Scientia Agraria, Curitiba, 11:387-391.

Rosier C.L., Frampton J., Goldfarb B., Blazich F.A. and Wise F.C. (2006). Improving the Rooting Capacity of Stem Cuttings of Virginia Pine by Severe Stumping of Parent Trees. Southern Journal of Applied Forestry, 30(4):172-181.

Sandor G. (2011). Changes of Auxin Content in the Rooting Zone of Hardwood Plum Cuttings. Thesis of PhD Dissertation. Corvinus University of Budapest. Pp3 .

Saumya M.T., Jijeesh C.M., Hrideek T.K. and Surendran T. (2014a). Standardization of Propagation through cuttings in Salacia fruticosa Heyne ex Lawson: a medicinal plant endemic to Western Ghats. Intl J Agric Environ Biotechnol, 7:565-570.

Saumya M.T., Surendran T. and Hrideek T.K. (2014b). Vegetative propagation for different physiological ages of Embelia ribes cuttings in different seasons. Res J Agric For Sci, 2:8-12.

Singh K.K., Chauhan S.S., Rawat J.M.S. and Rana D.K. (2015). Effect of different growing conditions and various concentrations of IBA on rooting and shooting of hardwood cuttings of Phalsa (Grewia asetica L.) under valley condition of Garwah Himalayas. Plant Archieves, 15: 131-136.

Singh, A. K. (2004). Influence of plant bio-regulators on growth and seed yield in French marigold (Tagetes patula L.). J. of Ornamental Hort., 7(2): 192-195.

Swedan A.A., Edriss M.H., Alhamed A. and Yusre A. (1993). Root initiation in the plum rootstock Marianna and the promotive effects of co-factors. Egyptian Journal of Horticulture, 20(1):43-55.

Szecskó V., Hrotkó K. and Stefanovits-Bányai É. (2006). Physiological Factors Influencing the Rooting of Plum Rootstocks' Hardwood Cuttings.

Tsipouridis C, T. Thomidis and A. Isaakidis. (2003). Rooting of peach hardwood and semi-hardwood cuttings. Australian Journal of Experimental Agriculture. 43: 1363-1368.

Tsipouridis C., Thomidis T. and Bladenopoulou S. (2006). Rhizogenesis of GF677, Early Crest, May Crest and Arm King stem cuttings during the year in relation to carbohydrate and natural hormone content. Sci. Hort., 108:200-204.

Wiegel K., Horn H. and Hock B. (1984). Endogenous auxin levels in terminal stem cuttings of Chrysanthemum morifolium during adventitious rooting. Physiol Plant, 61:422-428

Yeshiwas T., Melkamu A. and Getachew A. (2015). Effects of Indole Butyric Acid (IBA) and Stem Cuttings on Growth of Stenting-Propagated Rose in Bahir Dar, Ethiopia. World Journal of Agricultural Sciences, 11 (4): 191-197, ISSN 1817-3047. 